\title{
ANALISIS KEBUTUHAN PENGEMBANGAN BAHAN AJAR PADA KONSEP INTERAKSI ANTARMOLEKUL DAN PRINTER INKJET
}

\author{
Nina Adriani ${ }^{1}$, Inelda Yulita ${ }^{2}$, Amin Fatoni ${ }^{3}$, Dadan Hermawan ${ }^{4}$, Ahmad Mudzakir ${ }^{5}$ \\ Pendidikan Kimia, Universitas Maritim Raja Ali Haji ${ }^{1,2}$ \\ Kimia, Universitas Jenderal Soedirman ${ }^{3,4}$ \\ Pendidikan Kimia, Universitas Pendidikan Indonesia ${ }^{5}$ \\ Email: nina.adriani@umrah.ac.id
}

\begin{abstract}
Abstrak
Keterkaitan antara materi pembelajaran dengan kehidupan sekitar yang dikenal sebagai literasi sains menjadi hal yang penting saat ini untuk dilakukan oleh pendidik. Literasi sains menjadi suatu hal yang perlu dan terus dikembangkan, terutama dalam mengembangkan bahan ajar. Pelaksanaan penelitian untuk mencari tahu bagaimana keperluan dari calon guru terhadap bahan ajar yang akan dikembangkan pada konsep interaksi antarmolekul dan hubungannya terhadap printer inkjet. Analisis ini menggunakan angket wawancara dan soal konsepsi yang diberikan kepada mahasiswa pendidikan kimia untuk mengetahui keterkaitan antara pemahaman pada materi dan hubungan dengan konteks yang ada. Hasil data angket diolah menggunakan metode kualitatif deskriptif berdasarkan hasil penelitian. Hasilnya menyatakan bahwa $97 \%$ mahasiswa sudah mengetahui dan terbiasa menggunakan printer inkjet, tetapi hanya $49 \%$ yang paham bagaimana konsep materi interaksi antarmolekul pada konteks printer inkjet. 83\% mahasiswa menyatakan bahwa adanya keterkaitan antara materi kimia dan printer inkjet, tetapi hanya $11 \%$ yang memahami bagaimana keterkaitan interaksi antara tinta dan kertas dari segi ikatan kimia. Mahasiswa juga menyatakan bahwa sejumlah $89 \%$ membutuhkan penggunaan bahan ajar yang mengaitkan antar konsep interaksi antar molekul dan hubungannya terhadap printer inkjet. Berdasarkan hasil penelitian ini, maka akan dikembangkan suatu bahan ajar yang dapat menjelaskan hubungan antar konsep interaksi molekul dan konteks printer inkjet terhadap calon guru kimia.
\end{abstract}

Kata Kunci : Interaksi Antarmolekul, Literasi Sains, Printer Inkjet

\begin{abstract}
The link between learning materials and the surrounding known as scientific literacy is an important thing for educators to do today. Scientific literacy is needed and it continues to be developed, especially in developing teaching materials. This research is conducted to know the needs of prospective teachers for developing teaching materials on intermolecular interactions and its connection with the concept of an inkjet printer. This analysis used an interview worksheet and conceptual questions given to chemistry learning students to discover the correlation between the material and the relationship with the existing context. The outcomes of the worksheet data were constructed using descriptive qualitative methods. The results stated that $97 \%$ of students already knew and were familiar with inkjet printers, but only 49\% understood how the cognition of intermolecular interaction material in the circumstance of inkjet printers. $83 \%$ of students stated that there was a relationship between chemical materials and inkjet printers, but only $11 \%$ understood how the interactions between ink and paper were related in terms of chemical bonds. Students also stated that $89 \%$ required the use of teaching materials that linked the concept of interactions between molecules and their relationship with the context of an inkjet printer. Therefore, according to the conclusion of this research, teaching material is going to be developed that can explain the connection between the concepts of molecular interaction and the context of an inkjet printer to the prospective chemistry teachers.
\end{abstract}

Key Words : Intermolecular Interactions, Scientific Literacy, Inkjet Printers

\section{PENDAHULUAN}

Pembelajaran merupakan proses dengan pertemuan yang intens pada kegiatan belajar mengajar [1]. Pembelajaran sains merupakan pembelajaran yang mengaitkan antara konsep sains dengan aplikasinya 
dalam kehidupan. Suatu pembelajaran menjadi lebih bermakna jika dapat membangkitkan minat siswa untuk belajar dan pendidik dapat menghubungkan materi dengan kehidupan sekitar [2]. Berhasilnya suatu pembelajaran disebabkan oleh lengkapnya cakupan komponen pembelajaran, yaitu berupa tujuan, metode, bahan ajar, media dan evaluasi pembelajaran [3]. Bahan ajar dapat menjadi satu kunci penting dalam terciptanya sebuah efektivitas pembelajaran, sehingga jika bahan ajar tidak sesuai untuk proses pembelajaran, tentunya mempengaruhi proses itu sendiri [4].

Bahan ajar merupakan suatu hal yang penting, dibutuhkan pada pembelajaran dan telah disesuaikan dengan inti dan kompetensi pembelajaran [5]. Dosen sebagai pendidik diharapkan mampu untuk menyusun atau merancang bahan ajar dengan perannya untuk mencapai tujuan belajar dan proses pembelajaran dengan menggunakan bahan ajar [6]. Sifat accessible yang terdapat pada bahan ajar menjadi satu kunci dalam pengembangannya, sehingga hal ini sangat diperlukan untuk mengetahui konsepsi pada proses pembuatannya [7]. Bahan ajar yang biasa digunakan pendidik banyak bentuknya dan dikategorikan ke dalam beberapa jenis yaitu bahan ajar tampak, yang didengar, yang didengar sekaligus tampak dan lainnya [8]. Bahan ajar dapat menyesuaikan kebutuhan peserta didik dan lingkungan sekitarnya [9]. Materi interaksi antar molekul adalah salah satu bagian dari mata kuliah ikatan kimia. Konteks printer inkjet menjadi salah satu contoh pengaplikasian konsep materi interaksi antar molekul pada kehidupan nyata yang nantinya diajarkan oleh calon guru kimia yaitu mahasiswa.

Penelitian ini memiliki tujuan yakni menganalisis sejauh mana keperluan terhadap peningkatan dan perkembangan bahan ajar terkait konsep interaksi antarmolekul dengan konteks printer inkjet yang terdapat di mata kuliah ikatan kimia. Analisis kebutuhan bermanfaat untuk mengetahui jenis bahan ajar yang akan dibuat sehingga ia dapat diaplikasikan sesuai dengan tujuan dan materi yang diajarkan oleh pendidik. Pengembangan bahan ajar memiliki kontribusi yang besar terhadap keberhasilan suatu pembelajaran. Bahan ajar dibuat selaras dengan keadaan dan hasil analisis [10]. Tanpa adanya analisis kebutuhan, tujuan pembelajaran yang baik tidak akan tercapai melalui bahan ajar yang dibuat.

Hal penting adalah membangun kemampuan pendidik dalam menyiapkan pembelajaran serta membuat bahan ajar sesuai minat peserta didik [11]. Tentunya sesuai dengan pendapat [12] yang menyatakan peserta didik masih belum memahami bagaimana konsep materi kimia yaitu interaksi antarmolekul pada konteks printer inkjet dan perlu adanya bahan ajar untuk membantu meningkatkan literasi calon guru sebagai peserta didik.

\section{METODE}

Analisis kebutuhan untuk membuat bahan ajar materi dengan keterkaitan printer inkjet ini dilaksanakan di FKIP, UMRAH pada bulan September tahun 2020. Penelitian ini dilakukan terhadap pebelajar pendidikan kimia yang telah melaksanakan kelas ikatan kimia sebanyak 35 orang. Penelitian ini bersifat deskriptif kualitatif dengan mengadopsi hasil dari [12] dengan menggunakan 2 lembar angket analisis kebutuhan, yaitu angket lembar wawancara dan soal konsepsi tentang konteks printer inkjet. Pada lembar wawancara, beberapa aspek yang ditanyakan adalah : (1) persepsi mahasiswa tentang printer inkjet, (2) persepsi mahasiswa tentang komponen penyusun dan cara kerja printer inkjet, (3) keterkaitan antara materi kimia dan printer 
inkjet, (4) kebutuhan penggunaan bahan ajar. Sedangkan beberapa aspek yang ditanyakan pada lembar angket konsepsi interaksi antarmolekul pada printer inkjet adalah : (1) pengertian interaksi antarmolekul dan contohnya, (2) hubungan interaksi antarmolekul dengan teknologi termal inkjet, (3) interaksi antara tinta dan kertas dari segi ikatan kimia, (4) konsep viskositas pada printer inkjet.

Hasil wawancara dan konsepsi menggunakan persentase yang dijabarkan melalui rumus ini.

$$
\begin{aligned}
& \% \text { tanggapan } \\
& =\frac{\text { jumlah responden pemberi tanggapan }}{\text { jumlah responden seluruhnya }} \times 100 \%
\end{aligned}
$$

Hasil dalam persentase ini dikembangkan dalam bentuk kualitatif deskriptif, dimana data yang terkumpul dianalisis dan digambarkan sesuai dengan hasil yang didapat tanpa menyimpulkan kepada sesuatu hal yang bersifat biasa [13].

\section{HASIL DAN PEMBAHASAN}

Berdasarkan dari kedua hasil angket berupa lembar wawancara dan soal konsepsi terhadap calon guru mengenai printer inkjet analisis tentang interaksi molekul dan aplikasi printer inkjet terhadap calon guru kimia, dihasilkan data awal berupa persentase persepsi

\begin{tabular}{|c|c|c|c|}
\hline No & $\begin{array}{l}\text { Instrumen Penelitian Analisis } \\
\text { Kebutuhan }\end{array}$ & Kategori Isian Instrumen & Hasil (\%) \\
\hline 1. & Angket lembar wawancara & $\begin{array}{l}\text { a. Persepsi mahasiswa tentang printer inkjet. } \\
\text { b. Persepsi mahasiswa tentang komponen } \\
\text { penyusun dan cara kerja printer inkjet. } \\
\text { c. Keterkaitan antara materi kimia dan printer } \\
\text { inkjet. } \\
\text { d. Kebutuhan penggunaan bahan ajar. }\end{array}$ & $\begin{array}{l}97 \\
80 \\
83 \\
89\end{array}$ \\
\hline 2. & $\begin{array}{l}\text { Angket konsepsi interaksi } \\
\text { antarmolekul pada printer inkjet }\end{array}$ & $\begin{array}{l}\text { a. Pengertian interaksi antarmolekul dan } \\
\text { contohnya. } \\
\text { b. Hubungan interaksi antarmolekul dengan } \\
\text { teknologi termal inkjet. } \\
\text { c. Interaksi antara tinta dan kertas dari segi } \\
\text { ikatan kimia. } \\
\text { d. Konsep viskositas pada printer inkjet }\end{array}$ & $\begin{array}{l}49 \\
35 \\
11 \\
54\end{array}$ \\
\hline
\end{tabular}
mahasiswa pada Tabel 1 berikut.
Berdasarkan dari hasil data penelitian (Tabel 1), dapat dilihat hasil dari analisis kebutuhan yang telah dilakukan baik melalui angket lembar wawancara dan konsepsi tentang konteks printer inkjet. Pada kategori wawancara pada Gambar 1 persepsi mahasiswa tentang printer inkjet, sejumlah $97 \%$ mahasiswa sudah menggunakan dan mengaplikasikan printer inkjet sedangkan sisanya 3\% belum pernah menggunakan printer inkjet dan kurang memahami apa printer inkjet tersebut. Hal ini menunjukkan bahwa mahasiswa sudah akrab dan terbiasa dan selalu menggunakan printer inkjet dalam kehidupan sehari-hari sebagai mahasiswa. Penggunaan media secara langsung pada kehidupan menjadi dasar dalam membuat bahan ajar serta menunjang proses pembelajaran [14].

Persepsi mahasiswa tentang printer inkjet

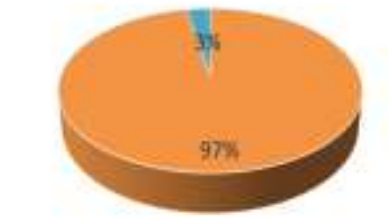

- Pernah menggunakan * Belum pernah

Gambar 1. Hasil Wawancara Mengenai Persepsi Mahasiswa tentang Printer Inkjet 
Printer inkjet yang sekarang beredar di pasaran sangat banyak jenis dan modelnya, tergantung selera pengguna dalam hal memilih kegunaan. Selain untuk mencetak, printer inkjet juga dapat mencopy dan menscan dokumen yang sudah ada. Sehingga printer inkjet ini dianggap multifungsi bagi penggunanya. Hal ini sesuai dengan pendapat bahwa peserta didik seharusnya memahami terlebih dahulu konsep awal dari materi berupa definisi dan fungsinya sehingga kesulitan dalam pembelajaran dapat diatasi dengan baik [15].

\section{Persepsi mahasiswa tentang komponen penyusun dan cara kerja printer inkjet}

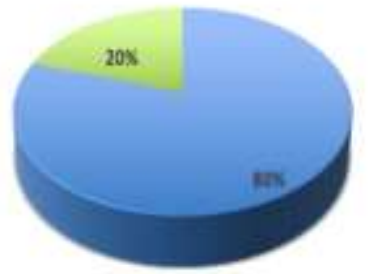

u Mengetahui uTidak mengetahui

\section{Gambar 2. Hasil Wawancara Mengenai Persepsi Mahasiswa tentang Komponen Penyusun dan Cara Kerja Printer Inkjet}

Berdasarkan hasil wawancara pada Gambar 2 menunjukkan bahwa sebanyak $80 \%$ mahasiswa sudah mengetahui tentang komponen penyusun dan cara kerja printer inkjet dengan baik, sedangkan $20 \%$ mahasiswa masih belum mengetahuinya.

Melalui beberapa hasil jawaban mengenai hal ini yaitu komponen penyusun printer inkjet berupa cartridge, printhead, paper tray, nozzle, tinta, USB dan stabilizer bar. Melalui jawaban ini, terlihat mahasiswa sudah cukup paham mengenai komponen penyusun dan cara kerja printer inkjet secara umum.
Pemahaman terhadap komponen dan cara kerja media secara tepat dapat meningkatkan semangat dan konsentrasi seluruh yang terkait dengan pembelajaran [16].

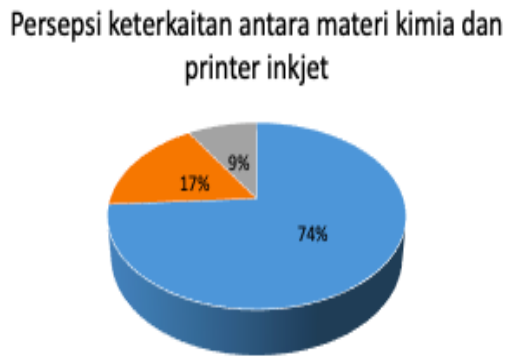

- Hidrokarbon, katan kimia, kimia kompleks

- Kimia organik dan anorganik

" Tidak ada jawaban

\section{Gambar 3. Hasil Wawancara Mengenai Persepsi Mahasiswa tentang Keterkaitan antara Materi Kimia dan Printer Inkjet}

Berdasarkan dari hasil Gambar 3 menunjukkan bahwa keterkaitan antara materi kimia cukup erat terhadap printer inkjet. Hal ini dapat dilihat dari hasil $74 \%$ menyatakan bahwa konteks printer inkjet dapat diterapkan pada materi hidrokarbon, ikatan kimia dan kimia kompleks, sejumlah $17 \%$ pada materi kimia organik dan anorganik. Sedangkan hanya sejumlah 9\% yang tidak menjawab, sehingga disimpulkan bahwa cukup banyak mahasiswa yang mengetahui tentang keterkaitan ini.

Meskipun mahasiswa sudah sangat sering menggunakan printer inkjet, tetapi pemahaman tentang konsep kimia pada materi printer inkjet masih sangat kurang. Pembelajaran yang seharusnya dilakukan dalam bidang pendidikan kimia adalah dapat menghubungkan makna pembelajaran yang diaplikasikan dengan baik antara konsep dan konteks yang terdapat dalam kehidupan [17]. 


\section{konsepsi pemahaman tentang pengertian interaksi antarmolekul dan contohnya

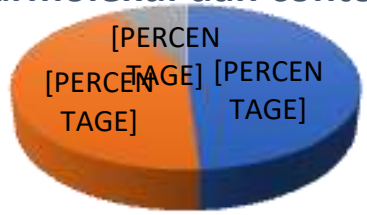 \\ Paham Sedikit paham Tidak paham \\ Gambar 4. Hasil Konsepsi Mengenai Pemahaman tentang Pengertian Interaksi Antarmolekul dan Contohnya}

Berdasarkan Gambar 4 tentang hasil konsepsi mengenai pemahaman tentang pengertian interaksi antarmolekul dan contohnya bahwa sejumlah $49 \%$ mahasiswa sudah paham tentang apa yang dimaksud dengan konsep interaksi antarmolekul. Sejumlah $43 \%$ mahasiswa hanya paham sebagian konsep, serta $8 \%$ mahasiswa yang tidak paham dengan konsepnya sama sekali karena tidak menjelaskan pengertian tentang interaksi molekul dan contoh yang sesuai dengan materi interaksi molekul. Pada perkembangan zaman seperti sekarang ini, pemahaman konsep dapat ditingkatkan melalui bahan ajar dengan menggunakan perkembangan teknologi yang ada [18].

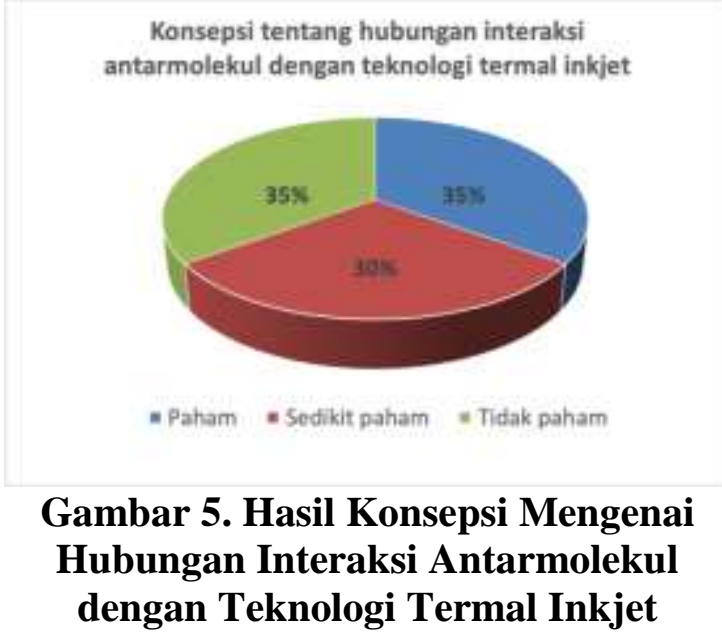

Tingkat pemahaman juga ditunjukkan dari hasil konsepsi mengenai hubungan interaksi antarmolekul dengan teknologi termal inkjet, hanya $35 \%$ yang sangat paham konsep mengenai hal ini seperti jawaban penggunaan teknologi termal inkjet yang mengandung elemen panas dan menghasilkan gelembung pada suhu 350$400^{\circ} \mathrm{C}$ dapat menyebabkan meningkatnya interaksi antarmolekul, sehingga tinta menguap dan menghasilkan tekanan dan memaksa tetes-tetes tinta keluar dari nozzle. Sebanyak 30\% mahasiswa yang sedikit paham mengenai konsep ini, dan $35 \%$ tidak paham sama sekali. Hal ini menunjukkan bahwa mahasiswa sudah mengenal secara fisik tentang printer inkjet dan menggunakan dengan baik, tetapi masih sedikit yang paham bagaimana konsep materi kimia yang berkaitan dengan printer inkjet, yaitu interaksi antarmolekul. Materi interaksi antarmolekul pada mata kuliah ikatan kimia ini membutuhkan pemahaman khusus dan mendalam yang mencakup tiga representasi, yaitu makroskopik, mikroskopik dan simbolik [19]. Ketiga representasi ini dapat bermanfaat sebagai alat untuk mendukung pembelajaran dan dapat mendukung perkembangan peserta didik. Hal ini yang harus dan wajib dipahami oleh peserta didik, sehingga konsep kimia pada printer inkjet dapat dengan mudah dipahami.

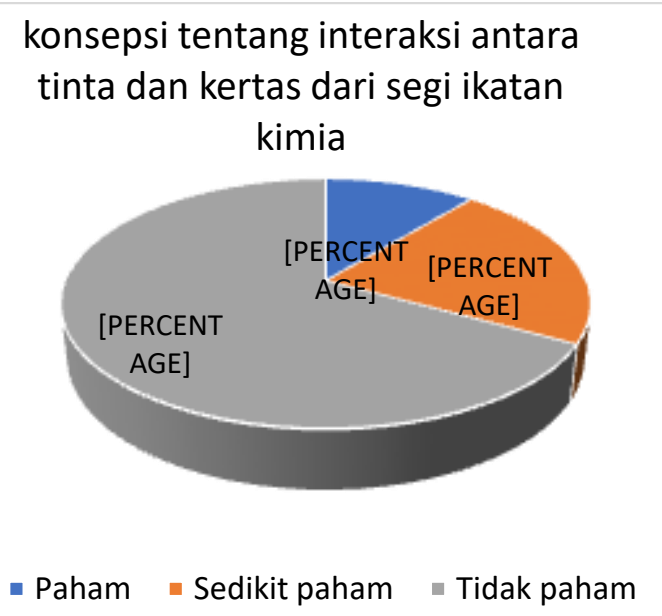

Gambar 6. Hasil Konsepsi Mengenai Interaksi antara Tinta dan Kertas dari Segi Ikatan Kimia 
Berdasarkan hasil data konsepsi juga bahwa hanya $11 \%$ yang paham tentang interaksi antara tinta dan kertas dari segi ikatan kimia pada materi konsep printer inkjet, hal ini tertera pada Gambar 6 . Masih banyak sekali mahasiswa yang belum paham akan konsep tinta pada printer inkjet ini, hanya sebatas lebih mengetahui bahwa printer inkjet bekerja menggunakan tinta. Seperti pada jawaban bahwa interaksi antara tinta dan kertas terlihat dari dihasilkannya tulisan ataupun gambar. Sebanyak 22\% mahasiswa masih sedikit paham tentang konsep, dan sejumlah $67 \%$ masih tidak paham tentang konsep ini. Ketidakpahaman peserta didik terhadap konsep pembelajaran secara umum karena kurangnya penerapan fenomena kimia dalam kehidupan seharihari terhadap materi pembelajaran [20].

\section{Konsepsi tentang konsep viskositas pada printer inkjet

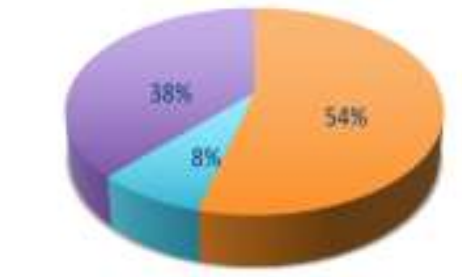 \\ wPaham = Sedikit paham = Tidak paham \\ Gambar 7. Hasil Konsepsi Mengenai Konsep Viskositas pada Printer Inkjet}

Selanjutnya, pada Gambar 7 hanya 54\% yang memahami bagaimana konsep viskositas pada printer inkjet. Padahal dengan memahami cara kerja serta konsep kimia pada printer inkjet ini, mahasiswa tentu akan dapat mengaitkan penggunaan printer inkjet dengan konsep viskositas, pada materi interaksi antarmolekul. Seperti pada jawaban bahwa viskositas adalah hal yang esensial pada printer inkjet, karena semakin besar interaksi antarmolekul yang terjadi, maka semakin besar viskositas. Sebanyak $8 \%$ mahasiswa sedikit paham tentang konsep ini dan 38\% tidak paham sama sekali. Kurangnya pemahaman mahasiswa terkait konsep dan konteks printer inkjet pada materi kimia, ini disebabkan salah satunya oleh kurangnya bahan ajar yang tersedia untuk menjelaskan tentang konsep printer inkjet. Tanpa adanya bahan ajar, maka proses pembelajaran akan terhambat dan tujuan pembelajaran tidak akan tercapai [21].

Diperlukan adanya bahan ajar yang tepat untuk memenuhi ketiga kebutuhan representasi pada konsep printer inkjet ini. Hal ini didukung juga oleh hasil data penelitian pada Gambar 8 bahwa sejumlah $89 \%$ membutuhkan bahan ajar dan tertarik untuk dikembangkan dan menggunakan bahan ajar. Pencapaian dari akhir proses pembelajaran, bahwa bahan ajar mempunyai misi dalam mewujudkan tujuan pembelajaran, sehingga dapat membantu peserta didik [22].

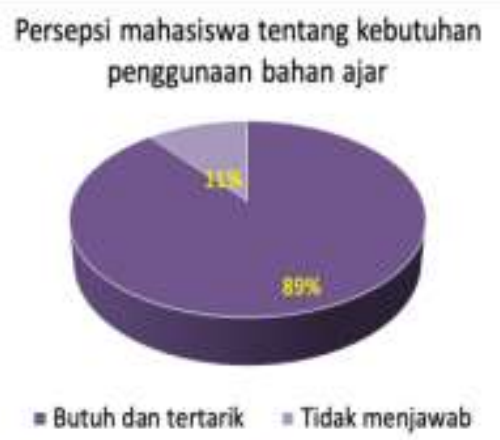

\section{Gambar 8. Hasil Wawancara Mengenai Persepsi Mahasiswa tentang Keterkaitan antara Materi Kimia dan Printer Inkjet}

\section{SIMPULAN}

Hasil angket wawancara dan konsepsi printer inkjet menunjukkan bahwa calon guru kimia sudah mengenal dengan baik mengenai printer inkjet, tetapi belum terlalu memahami bagaimana keterkaitan materi interaksi antarmolekul terhadap printer inkjet. Ini menyebabkan timbulnya kebutuhan dari calon guru untuk 
dikembangkan bahan ajar yang sesuai. Keterkaitannya antar konsep dan konteks dapat diaplikasikan pada kehidupan sekitar oleh peserta didik.

\section{UCAPAN TERIMA KASIH}

Peneliti menghaturkan rasa syukur yang sangat besar dan ucapan terhadap Direktorat Riset dan Pengabdian Masyarakat (DRPM) Kementerian Riset, Teknologi, dan Pendidikan Tinggi Republik Indonesia terhadap bantuan keuangan pada penelitian ini dan peneliti bisa menyelesaikan penelitian secara maksimal.

\section{DAFTAR PUSTAKA}

[1] A. P. Dewi, A. Putri, D. K. Anfira dan B. A. Prayitno, "Profil Keterampilan Kolaborasi Mahasiswa pada Rumpun Pendidikan MIPA," Pedagogia Jurnal Ilmu Pendidikan, vol. 18, no. 01, pp. 57-72, 2020.

[2] A. Sujana, A. Permanasari, W. Sopandi dan A. Mudzakir, "Literasi Kimia Mahasiswa PGSD dan Guru IPA Sekolah Dasar," Jurnal Pendidikan IPA Indonesia, vol. 3, no. 1, pp. 5-11, 2014.

[3] A. W. Sabekti dan N. Adriani, "Analisis Kebutuhan Pengembangan Media Pembelajaran Berbasis Android untuk Mata Kuliah Kimia Hidrokarbon," in Prosiding Seminar Nasional Pendidikan Kimia Fisika Biologi, Surakarta, 2018.

[4] M. Arsanti, "Pengembangan Bahan Ajar Mata Kuliah Penulisan Kreatif Bermuatan Nilai-Nilai Pendidikan Karakter Religius bagi Mahasiswa Prodi PBSI, FKIP, Unissula," Jurnal Kredo, vol. 1, no. 2, pp. 71-90, 2018.

[5] A. E. Putri, "Analisis Kebutuhan Bahan Ajar Berbasis Literasi Digital Nilai-Nilai Kearifan Lokal pada Tradisi Saprahan di Pontianak," Yupa: Historical Studies Journal, vol. 3, no.
1, pp. 1-7, 2019.

[6] A. Kusumam, Mukhidin dan B. Hasan, "Pengembangan Bahan Ajar Mata Pelajaran Dasar dan Pengukuran Listrik untuk Sekolah Menengah Kejuruan," Jurnal Pendidikan Teknologi dan Kejuruan, vol. 23, no. 1, pp. 28-39, 2016.

[7] I. Yulita, "Analisis Prekonsepsi Siswa terhadap Kemampuan Menghubungkan Konteks Air Laut dengan Konten Hakikat Ilmu Kimia Kelas X SMA," Jurnal Pendidikan Sains, vol. 6, no. 1, pp. 64-72, 2018.

[8] Effiong, O. Ekpo and C. E. Igiri, "Impact of Instructional Materials in Teaching and Learning of Biology in Senior Secondary Schools in Yakurr LG A," International Letters of Social and Humanistic Sciences, vol. 62, pp. 27-33, 2015.

[9] P. Rosalia, Yuniawatika dan S. Murdiyah, "Analisis Kebutuhan Bahan Ajar Siswa di Kelas III SDN Bendogerit 2 Kota Blitar," Premier Educandum: Jurnal Pendidikan Dasar dan Pembelajaran, vol. 10, no. 2, pp. 125-137, 2020.

[10] S. N. Rohmah, Yuniawatika dan S. Madyono, "Analisis Kebutuhan Bahan Ajar Booklet Bangun Datar dan Sifatsifatnya untuk Siswa Sekolah Dasar/Madrasah Ibtidaiyah," Madrasah: Jurnal Pendidikan dan Pembelajaran Dasar, vol. 12, no. 2, pp. 106-117, 2020.

[11] H. Rahmadani, Y. Roza and A. Murni, "Analisis Kebutuhan Bahan Ajar Matematika Berbasis Teknologi Informasi (TI) di SMA IT Al Bayyinah Pekanbaru," Juring (Journal of Research in Mathematics Learning), vol. 1, no. 1, pp. 91-98, 2018.

[12] I. Yulita, "Pre-Konsepsi Peserta Didik terhadap Konsep Interaksi 
Antarmolekul, Printer Inkjet dan Hubungan Keduanya," Jurnal Zarah, vol. 4, no. 1, pp. 9-24, 2016.

[13] Sugiyono, Metode Penelitian Kuantitatif, Kualitatif dan $R \& D$, Bandung: Alfabeta, 2012.

[14] T. Badengo dan Suparman, "Analisis Kebutuhan Bahan Ajar Berbasis Realistic Mathematics Education (RME) untuk Meningkatkan Kemampuan Berpikir Kritis Kreatif Siswa Kelas VII SMP Muhammadiyah 1 Depok," in Seminar Nasional Pendidikan Matematika Ahmad Dahlan, Yogyakarta, 2018.

[15] A. F. Safitri, H. R. Widarti dan D. Sukarianingsih, "Identifikasi Pemahaman Konsep Ikatan Kimia," Jurnal Pembelajaran Kimia, vol. 3, no. 1, pp. 41-50, 2018.

[16] Abdussakir, "Penggunaan Komputer untuk Pembelajaran Matematika," Madrasah: Jurnal Pendidikan dan Pembelajaran Dasar, vol. 5, no. 2, pp. 117-133, 2013.

[17] S. Rahayu, A. L. Chandrasegaran, D. F. Treagust, M. Kita and S. Ibnu, "Understanding Acid-Base Concepts: Evaluating the Efficacy of a Senior High School Student-Centered Instructional Program in Indonesia," International Journal of Science and Mathematics Education, vol. 9, no. 6, pp. 1439-1458, 2011.

[18] R. Agustina dan N. Farida, "Analisis Kebutuhan Pengembangan Bahan
Ajar Matematika bagi Siswa Low Vision," Jurnal Pendidikan Matematika Raflesia, vol. 4, no. 2, pp. 58-66, 2019.

[19] M. Muchson, "Pengembangan Multimedia Pembelajaran Interaktif Topik Gaya Antarmolekul pada Matakuliah Ikatan Kimia," Jurnal Pendidikan Sains, vol. 1, no. 1, pp. 14-25, 2013.

[20] N. K. Wardhani, Prayitno dan F. Fajaroh, "Studi Pemahaman Konsep dan Miskonsepsi Calon Guru Kimia pada Topik Struktur Atom Menggunakan Instrumen Diagnostik Two-Tier," Jurnal Pembelajaran Kimia (J-PEK), vol. 1, no. 2, pp. 3841, 2016.

[21] K. A. Syairi, "Pengembangan Bahan Ajar Bahasa Arab," Dinamika Ilmu, vol. 13, no. 1, pp. 51-66, 2013.

[22] K. Romansyah, "Pedoman Pemilihan dan Penyajian Bahan Ajar Mata Pelajaran Bahasa dan Sastra Indonesia," Jurnal Logika, vol. 17, no. 2, pp. 59-66, 2016. 